\title{
Influence of spawning procedure on gametes fertilization success in Salminus hilarii Valenciennes, 1850 (Teleostei: Characidae): Implications for the conservation of this species
}

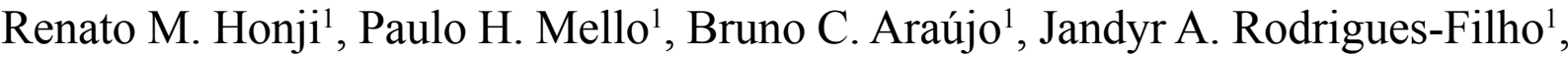 \\ Alexandre W. S. Hilsdorf ${ }^{2}$ and Renata G. Moreira ${ }^{1}$
}

Artificial reproduction and gamete fertilization were evaluated in Salminus hilarii wild and domesticated broodstocks. Wild and domesticated broodstocks were artificially induced to reproduction using a carp pituitary treatment. Four groups were considered: Group 1 (G1), fish caught in the wild maintained for three years in the same conditions as the domesticated broodstocks and spawned naturally; Group 2 (G2), broodstock born and raised in captivity and spawned naturally; Group 3 (G3), wild broodstocks, which were manually stripped for gamete collection and dry fertilization; and Group 4 (G4), domesticated males and females, also manually stripped. Oocytes, eggs, and larvae were sampled at different time intervals throughout embryonic development. Yolk sac absorption occurred approximately $24-29 \mathrm{~h}$ after hatching. Twenty-six $\mathrm{h}$ after hatching, the larvae mouths opened. Cannibalism was identified just 28-30 h after hatching. There was no morphological difference in embryonic development among all groups. The number of released eggs per gram of female was: G1: $83.3 \pm 24.5$ and G2: 103.8 \pm 37.4 ; however, the fertilization success was lower in G2 (42.0 $\pm 6.37 \%)$ compared with G1 $(54.7 \pm 3.02 \%)(\mathrm{P}=0.011)$. Handstripping of oocytes was not successful and the fertilization rate was zero. The reproduction of this species in captivity is viable, but it is necessary to improve broodstock management to enhance fertilization rates and obtain better fingerling production for restocking programs.

A reprodução artificial e fertilização dos gametas foram avaliados em reprodutores selvagens e de cativeiro de Salminus hilarii. Reprodutores selvagens e de cativeiro foram induzidos artificialmente à reprodução utilizando hipófise de carpa. Quatros grupos foram considerados: Grupo 1 (G1), peixes capturados na natureza, mantidos por três anos nas mesmas condições de reprodutores de cativeiro e desovados naturalmente; Grupo 2 (G2), reprodutores nascidos e criados em cativeiro e desovados naturalmente; Grupo 3 (G3), reprodutores selvagens que foram extrusados manualmente para a coleta de gametas e fertilização a seco; e Grupo 4 (G4), com machos e fêmeas domesticadas, também extrusados manualmente. Oócitos, ovos e larvas foram amostrados em diferentes intervalos de tempo ao longo do desenvolvimento embrionário. A absorção do saco vitelínico ocorreu aproximadamente 24-29 h após a eclosão. Vinte e seis h após a eclosão, as larvas abriram a boca. O canibalismo foi identificado apenas 28-30 h após a eclosão. Não houve diferença morfológica no desenvolvimento embrionário entre todos os grupos. O número de ovos liberados por grama de fêmea foi: G1: 83,3 $\pm 24,5$ e G2: 103,8 \pm 37 ,4; embora, o sucesso na fertilização tenha sido menor no G2 (42,0 $\pm 6,37 \%)$ em comparação com G1 $(54,7 \pm 3,02 \%)(\mathrm{P}=0,011)$. A extrusão manual dos oócitos não foi bem sucedida e a taxa de fertilização foi zero. A reprodução em cativeiro desta espécie é viável, mas é necessário um melhor manejo dos reprodutores para aumentar as taxas de fertilização, visando a obtenção de uma melhor produção de alevinos para os programas de repovoamento.

Key words: Early development, Growth, Reproduction, Tabarana.

${ }^{1}$ Instituto de Biociências, Universidade de São Paulo. Rua do Matão, Travessia 14, 321, 05508-900 São Paulo, SP, Brazil. honjijp@usp.br(RMH), phmello@usp.br (PHM), brunocavar@usp.br (BCA), jajajandyr@gmail.com (JARF), renatagm@ib.usp.br (RGM) (corresponding author) ${ }^{2}$ Núcleo Integrado de Biotecnologia, Universidade de Mogi das Cruzes. Cx. Postal 411, 08701-970, Brazil. wagner@umc.br 


\section{Introduction}

The neotropical fish genus Salminus is a representative of the family Characidae (included in the subfamily Salmininae by Mirande, 2010), order Characiformes, and class Actinopterygii (Lima et al., 2003; Lima \& Britski, 2007). Currently, four species are described for the genus Salminus: S. affinis Steindachner, 1880, S. hilarii Valenciennes, 1850, S. franciscanus Lima \& Britski, 2007, and S. brasiliensis Cuvier, 1816 (=S. maxillosus) (Lima et al., 2003, 2007; Lima \& Britski, 2007).

Salminus hilarii, commonly known as "dourado branco" or "tabarana" in Portuguese and "dorada" in Spanish, is a migratory species that inhabits the basins of the upper Paraná, São Francisco, Tocantins, upper Amazonas and upper Orinoco River basins (Lima et al., 2003, 2007). It is a "rheophilic", carnivorous species that plays an important role in the food chain in the upper Tietê River basin (located in the Paraná River basin) where the fish migrate upstream to reproduce during the rainy season (Godoy, 1975).

Shoals of tabarana were commonly observed in tributaries of the Tietê River in the City of São Paulo (von Ihering, 1929). Anthropogenic disturbances such as domestic and industrial pollution and river disruption by dam construction in the upper Tietê River basin have reduced and jeopardized the local population of the $S$. hilarii species, which is currently classified as "almost threatened" in the São Paulo State (São Paulo, 2008). It is important to emphasize that $S$. hilarii can be used as an environmental indicator, given its high degree of environmental selectivity.

Observations on S. hilarii oocyte development in wild and domesticated animals showed that females do not have postovulatory follicles when upstream migration is blocked, indicating that they fail to ovulate and spawn in this situation (Honji et al., 2009) but reach a maturation stage suitable for inducing ovulation by hormone manipulation (Zohar \& Mylonas, 2001; Mylonas et al., 2010), as is observed for most of the migratory fish species (Gomes \& Urbinati, 2005; Ituassú et al., 2005; Porto-Foresti et al., 2005; Urbinati \& Gonçalves, 2005; Weingartner \& Zaniboni-Filho, 2005). However, hormone manipulation requires species-specific techniques, which are needed to achieve successful fertilization, such as accurate timing for ovulation and stripping, an appropriate density and contact time between gametes (Zaniboni-Filho \& Barbosa, 1996; Butts et al., 2009; Mylonas et al., 2010). There are many successful and established protocols for induced spawning and culture techniques for some SouthAmerican rheophilic fish (Zaniboni-Filho \& Barbosa, 1996; Castagnolli \& Castagnolli, 2005; Zaniboni-Filho \& Weingartner, 2007). Nevertheless, the information concerning hormonally induced reproduction in the genus Salminus is limited for S. brasiliensis (Amutio et al., 1986; Zaniboni-Filho \& Barbosa, 1996; Sato et al., 1997; Weingartner \& Zaniboni-Filho, 2005).

Currently, the main problem faced by conservation biologists in reproducing Salminus hilarii is a lack of knowledge about the larval period, which stems from a lack of ecological, behavioral, and ontogenetic studies on this fish. One of the most successful actions available for conservation biologists to protect critically endangered species is artificial reproduction because it has a higher chance of successful fertilization, which does not always occur in captive-breeding programs (Philippart, 1995; Wikelski \& Cooke, 2006). Applying the knowledge of $S$. hilarii reproductive biology to conservation programs requires an understanding of the reproductive mechanisms, artificial reproduction techniques, and ontogenetic development of this species. The information collected for conservation programs can also be used in fish restocking programs. Taking these points into consideration, the main goals of this study were: 1) to obtain data on a hormonal induction protocol to produce $S$. hilarii fingerlings 2) to compare the success of gamete fertilization between wild and domesticated females, either by natural spawning or under stripping of gametes, and 3) to describe the major events in the growth of $S$. hilarii larvae under culture conditions.

\section{Material and Methods}

In this study, four experimental groups were considered and compared with each other. Wild $S$. hilarii females and males were captured in 2004 in the upper reaches of the Tietê River basin between the towns of Mogi das Cruzes and Biritiba Mirim, São Paulo State, Brazil (between 2332' 45.3'S 46 08' $03.2^{\prime \prime} \mathrm{W}$ and $23^{\circ} 34^{\prime} 36.5^{\prime \prime} \mathrm{S} 45^{\circ} 54^{\prime} 23.9^{\prime \prime} \mathrm{W}$ ) using artisanal fisheries (considered in the present research as broodstocks of wild origin - G1). Wild broodstocks were captured and animals were transported individually to the Ponte Nova Hatchery $\left(23^{\circ} 35^{\prime} 33.8^{\prime \prime} \mathrm{S} 45^{\circ} 58^{\prime} 09.1^{\prime \prime} \mathrm{W}\right)$. The broodstocks ( $100 \%$ survival) were maintained in two ponds $\left(300 \mathrm{~m}^{2}\right.$ each) and fed with commercial extruded feed for carnivorous $(40 \%$ crude protein, Purina ${ }^{\circledR}$ TC40). Sampling methods are according to Honji et al. (2009).

After assessing the maturation stages of the gonads each month (described by Honji et al., 2009), the first artificial breeding of the wild males and females in captivity was scheduled for December 2005 using a carp pituitary treatment. The gamete release occurred naturally (without stripping the broodstock) and the fingerlings produced (first-generation offspring, F1) were stocked in the fish farm ponds for future broodstock captive rearing. These fish were considered to be domesticated broodstocks for the purposes of this study (G2).

Salminus hilarii fingerlings (G2) were stocked from December 2005 to December 2007 in ponds $\left(300 \mathrm{~m}^{2}\right)$ and also fed during this period with the same described commercial extruded feed. In 2007, the females were sexually mature enough to perform the hormonal induction protocol, and both G1 and G2 were induced using the carp pituitary treatment (broodstock selection, hormonal induction and spawning are shown below). In December/2007, these groups (G1 and G2) were allowed to spawn naturally.

Additionally, a third experimental group (G3) was considered, in which both males and females were stripped, and dry gamete fertilization was performed on wild females. 
In the fourth group (G4), domesticated males and females were also manually stripped and dry gamete fertilization was also performed in domesticated animals (December 2007). Water quality parameters such as temperature and dissolved oxygen were monitored daily with an oximeter (model 55; YSI, Yellow Springs, $\mathrm{OH})$.

\section{Broodstocks selection, hormonal induction and spawning}

The females with a large and soft abdomen, and also a swollen gonadal papilla were selected for hormonal induction. A biopsy procedure was performed, cannulating the gonoduct with fine polyethylene tubing ( $5 \mathrm{~mm}$ diameter) attached to a plastic syringe through the gonad papilla. Several oocytes were collected to better examine their size, appearance, and diameter homogeneity, which are important criteria used to establish the spawning readiness of a total spawning species such as S. hilarii (Harvey \& Carolsfeld, 1993; Honji et al., 2009). The homogeneity of oocytes' diameters was analyzed under a stereomicroscope (Zeiss, Stemi - SV6) with an ocular micrometer (Coleman), taking into account the data shown by Honji et al. (2009). Running sperm was detected in males using a soft abdominal massage, and these individuals were selected. To control factors other than the influence of the female during the artificial breeding process, the males used in all experimental groups were domesticated broodstocks (F1).

Animals were selected in the ponds and transferred to laboratory tanks $\left(3.6 \mathrm{~m}^{2}\right)$ where a routine protocol for artificial reproduction was performed (von Ihering \& Azevedo, 1934, 1936 modified) using two intraperitoneal injections of carp pituitary extract (cPE). Doses were $0.5 \mathrm{mg} \mathrm{cPE} / \mathrm{kg}$ (first injection) and $5.0 \mathrm{mg} \mathrm{cPE} / \mathrm{kg}$ (second injection) diluted in $0.9 \%$ sodium chloride solution (considering $1.0 \mathrm{ml}$ in each dose). The second injection was administered $10 \mathrm{~h}$ after the first. Males received only one cPE injection ( $3 \mathrm{mg} \mathrm{cPE} / \mathrm{kg}$ ) that coincided with the females' second injection. In both G1 and G2, 5 females and 15 males were used for artificial reproduction (in a ratio of 1:3 for each induction). The summary of the dosages used in these protocols is shown in Table 1.

Between the interval of the first and the second injections, the females were kept in individual tanks in the laboratory under identical conditions, i.e., the same temperature, water quality parameters, and tank size. Following the final hormonal induction, males and females were kept together to allow natural spawning and further fertilization. Subsequently, the water flow in the tanks was increased and the water temperature was monitored once more. Additionally, four artificial reproductions were performed on different animals on different dates using the same protocol.

Spawning occurred naturally in the laboratory tanks (G1 and G2), and eggs were transferred to four 60-L fiberglass conical incubators, where they were maintained for 3 days until hatching and yolk-sac absorption. After this period, the larvae were transferred to horizontal fiberglass incubators $\left(0.5 \mathrm{~m}^{2}\right)$, where they were fed with Artemia sp. nauplii for 8 days.

The third (G3) and fourth (G4) groups were established for the purpose of comparing eggs and larval development when males and females were stripped. The dry stripped oocytes from 5 females were mixed with sperm from 10 males (1:2 ratio) in a dry plastic containers and water was then added for hydration and further fertilization. This procedure followed an established and successful protocol described for a closely related species, $S$. brasiliensis (Amutio et al., 1986; Zaniboni-Filho \& Barbosa, 1996; Zaniboni-Filho \& Weingartner, 2007), but was modified to include the procedure proposed by Weingartner \& Zaniboni-Filho, (2005) that consists of adding 3-5 times the water volume normally used for other species. This higher water volume was maintained for 30 to $40 \mathrm{~s}$, and then an even higher volume (about 5 times the initial volume) was added. After this procedure, the eggs were also transferred to $60-\mathrm{L}$ conical incubators.

In all groups, the estimated number of oocytes in S. hilarii was calculated indirectly by weighing the eggs and counting subsamples in triplicate (Caneppele et al., 2009). After spawning (natural or stripped), the females were transferred back into their original ponds ( $100 \%$ survival).

\section{Egg and larval analysis}

Egg and larval samples were taken from fertilization every $4 \mathrm{~h}$ until the fifth day after hatching (DAH) to observe embryonic development. From the $6^{\text {th }} \mathrm{DAH}$ to the $11^{\text {th }} \mathrm{DAH}$,

Table 1. Data on Salminus hilarii reproduction at the Ponte Nova Fish Farm during their reproductive periods (from: 2005 to 2007). Four artificial reproductions for G1 and G2 and two artificial reproductions for G3 and G4 were obtained on different days using different animals. Data are presented as the mean \pm Standard error of the mean.

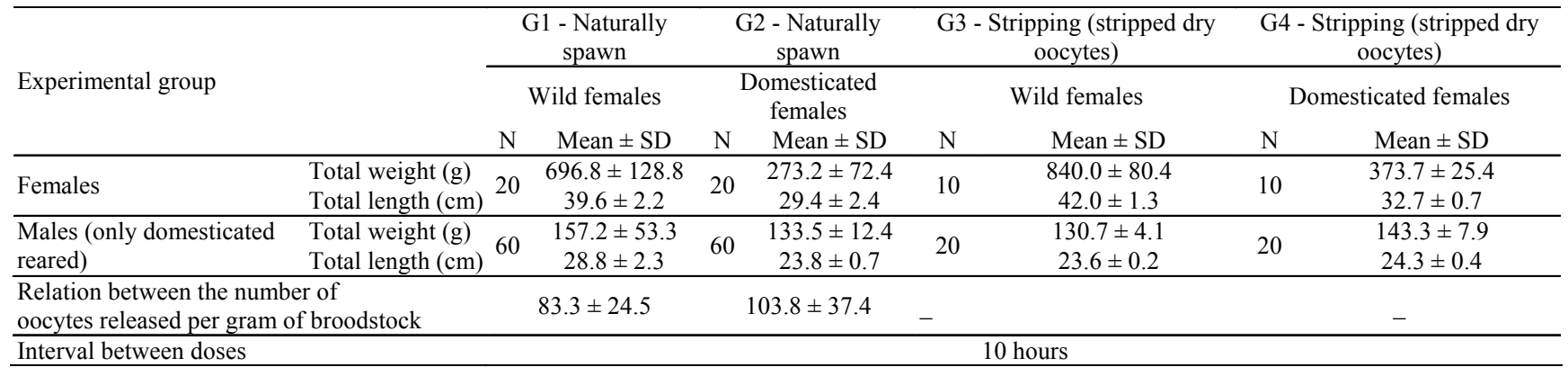


one sample was taken per day, and from the $12^{\text {th }}$ to the 90 DAH, one sample was taken per week. Eggs, embryos, and larvae were analyzed under a stereomicroscope.

The fertilization rate was calculated six hours after placing the eggs in the conical incubator ( $\mathrm{F}=$ (number of fertilized eggs $\mathrm{x} 100$ )/number of total eggs) (Vazzoler, 1981, 1996). Comparisons were made using an analysis of variance (one-way ANOVA), followed by the Student-Newmann-Keuls (SNK) test for parametric analyses or a Tukey test for non-parametric analyses. In all analyses, the differences were considered to be significant when $p<0.05$ (Zar, 1999). These analyses were performed using the statistical software SigmaStat Ver. 3.10 for Windows (Systat Software, San Jose, CA). Additionally, egg and larval samples were preserved as histological slices for the collection of the Laboratório de Metabolismo e Reprodução de Organismos Aquáticos (LAMEROA), Instituto de Biociências da Universidade de São Paulo.

\section{Results}

\section{Water quality}

Water quality parameters recorded throughout the experiment are show in Table 2. The average water temperature and oxygen concentration during the first and second doses were respectively, $26.8 \pm 0.9^{\circ} \mathrm{C}$ and $5.7 \pm 0.1 \mathrm{mg} / \mathrm{L} ; 24.9 \pm 0.7^{\circ} \mathrm{C}$ and $6.3 \pm 0.3 \mathrm{mg} / \mathrm{L}$. The average water temperature and oxygen concentration during spawning was $25.8 \pm 0.9^{\circ} \mathrm{C}$ and $6.7 \pm 0.2$ $\mathrm{mg} / \mathrm{L}$. Additionally, the average annual water temperature and oxygen concentration was $22.8 \pm 0.6^{\circ} \mathrm{C}$ and $6.5 \pm 0.1 \mathrm{mg} / \mathrm{L}$.

\section{Broodstocks selection, hormonal induction and spawning}

Mature $S$. hilarii broodstocks were identified from October to February. Males were smaller than females, and this difference was observed in all experimental groups (Table 1). In G1, it was not possible to establish the age of the animals because the specimens were collected from the wild, but all animals were adults (they reproduced in 2005 and 2007), and were consequently older than the $\mathrm{G} 2$ animals. However, considering that the broodstocks were reared in captivity, the age of first sexual maturation in G2 was 2 years for females and 1 year for males (the latter were already producing milt in December 2006).

Regarding the number of oocytes released per kg (weight) of broodstock, there was a small increase in G2 compared to G1 (103.8 \pm 37.4 and $83.3 \pm 24.5$, respectively). However, no significant difference in number of oocytes was observed between the experimental groups (Table 1).

Table 2. Data on water quality during the period of artificial reproduction at Ponte Nova Fish Farm. Data are presented as the mean \pm standard error of the mean.

\begin{tabular}{lcc}
\hline Period of artificial reproduction & $\begin{array}{c}\text { Water } \\
\text { temperature }\left({ }^{\circ} \mathrm{C}\right)\end{array}$ & $\begin{array}{c}\text { Dissolved } \\
\text { oxygen }(\mathrm{mg} / \mathrm{L})\end{array}$ \\
\hline First injection $(0.5 \mathrm{mg} \mathrm{cPE} / \mathrm{kg})$ & $26.8 \pm 0.9$ & $5.7 \pm 0.1$ \\
Second injection $(5 \mathrm{mg} \mathrm{cPE} / \mathrm{kg})$ & $24.9 \pm 0.7$ & $6.3 \pm 0.3$ \\
Spawning & $25.8 \pm 0.9$ & $6.7 \pm 0.2$ \\
Annual mean & $22.8 \pm 0.6$ & $6.5 \pm 0.1$ \\
\hline
\end{tabular}

When the animals were close to spawning, their behavior was very similar to other teleosts that spawn naturally. Females and males started swimming faster, coming near the water surface, and sometimes even jumping out of the water.

\section{Eggs and larvae analysis}

Ovulation occurred within 130 - $170(156 \pm 3.14)$ hourdegrees (HD), calculated after the second cPE injection. This index was important for monitoring natural spawning for G1 and $\mathrm{G} 2$ and was considered for hand-stripping of oocytes in G3. Oocytes from wild females were brown, while those obtained from domesticated females were green-bluish. However, specimens from G1 and G2 showed similar anatomic and histomorphologic characteristics, hatching times, embryonic development and number of stripped oocytes per gram of female.

Conversely, the fertilization rate was higher for the broodstocks from the wild type (G1), $54.7 \pm 3.02 \%$, when compared to $\mathrm{G} 2,42.0 \pm 6.37 \%(\mathrm{P}=0.011)$ (Fig. 1). In all groups, females presented both vitellogenic and atretic oocytes (Figs. $2 \mathrm{a}$ and $2 \mathrm{~b}$, respectively), and a positive response to hormonal manipulation was observed, i.e., they spawned. However, only in G3 and G4 the fertilization rate was zero for all females stripped (Fig.1). Considering that no fertilization was observed for G3 and G4, the following morphological description was based on eggs and larvae from G1 and G2.

The oocytes were spherical, transparent, were $1 \mathrm{~mm}$ in diameter just after spawning and were 3.5-4.0 $\mathrm{mm}$ after hydration. It was possible to observe some stages of embryo development in S. hilarii eggs, although it was not a focus of this study. Eggs developed quickly reaching the end of gastrulation in $4 \mathrm{~h}$, at which point some eggs experienced blastopore closure. In $8 \mathrm{~h}$, the embryos were apparent, and after $12 \mathrm{~h}$, the embryo tail was free from the yolk sac. Embryogenesis lasted 16 hours at $26.4^{\circ} \mathrm{C}$, after which the larvae hatched, which were $4.5-5.0 \mathrm{~mm}$ in length.

\section{Fertilization rates}

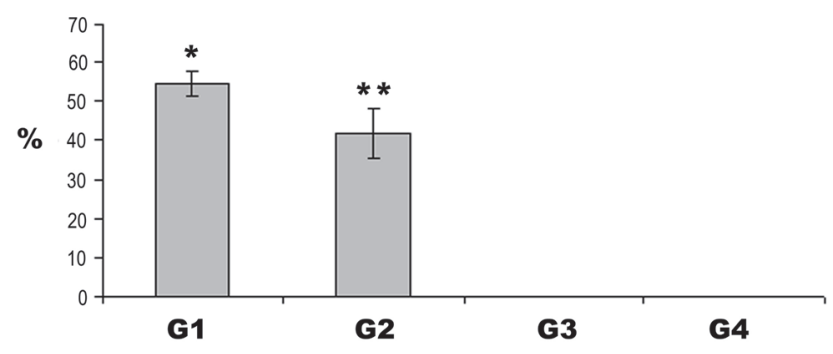

Fig. 1. Fertilization rates of Salminus hilarii for G1 (wild broodstock), G2 (domesticated broodstock), G3 (wild females, manually stripped) and G4 (domesticated females, manually stripped) at the Ponte Nova Fish Farm. Values (mean \pm standard error of the mean) followed by different symbol are significantly different between experimental groups. 
The visual macroscopic absorption of the yolk sac occurred from 24 to $29 \mathrm{~h}\left(26.5 \pm 0.5^{\circ} \mathrm{C}\right)$ after hatching (HAH). In this stage, the larvae were $7-8 \mathrm{~mm}$ long. At this time, the larval mouths opened, and intense cannibalism began at 28$30 \mathrm{HAH}$ (Fig. 2c, d) when the larval length was $8-9 \mathrm{~mm}$. At this time, we initiated the exogenous feeding of $S$. hilarii larvae with Artemia nauplii. By the $9^{\text {th }} \mathrm{DAH}$, the larval length was 1-2 $\mathrm{cm}$, and cannibalism was still intense. By the $30^{\text {th }} \mathrm{DAH}$, the fingerlings were $7 \mathrm{~cm}$ long, and at $90^{\text {th }} \mathrm{DAH}$, their length was approximately $12 \mathrm{~cm}$.

All major events in the growth of $S$. hilarii larvae are summarized in Fig. 3.

\section{Discussion}

Our study of S. hilarii reproduction revealed that G1 and G2 females have a positive response to artificial reproduction in December, corroborating the data that the reproductive period for this species in the upper reaches of the Tietê River occurs from September to February (Honji et al., 2009). In 2005, the first artificial breeding was achieved. Subsequent monitoring of the juveniles until maturation showed, for the first time, that $S$. hilarii males and females become mature at one year and two years old, respectively. Previous studies had only been able to base maturity (not first maturation) on total length (Nakatani et al., 2001; Andrade et al., 2006) due to the wild origin of the animals.

In the upper Tietê River basin, the reproductive cycle of S. hilarii occurs between September and February, when oocyte development is synchronous in each group and spawning is total (Honji et al., 2009). Slightly different intervals were observed in the Sorocaba River (Takahashi, 2006), in the Mogi Guaçu River (Godoy, 1975) and in the Três Marias reservoir, in Minas Gerais (Andrade et al., 2006), but these were included in the period observed in the present study.

The methods used to judge female readiness for hormonal manipulation were considered appropriate and include the assessment of external appearance and gonadal histology
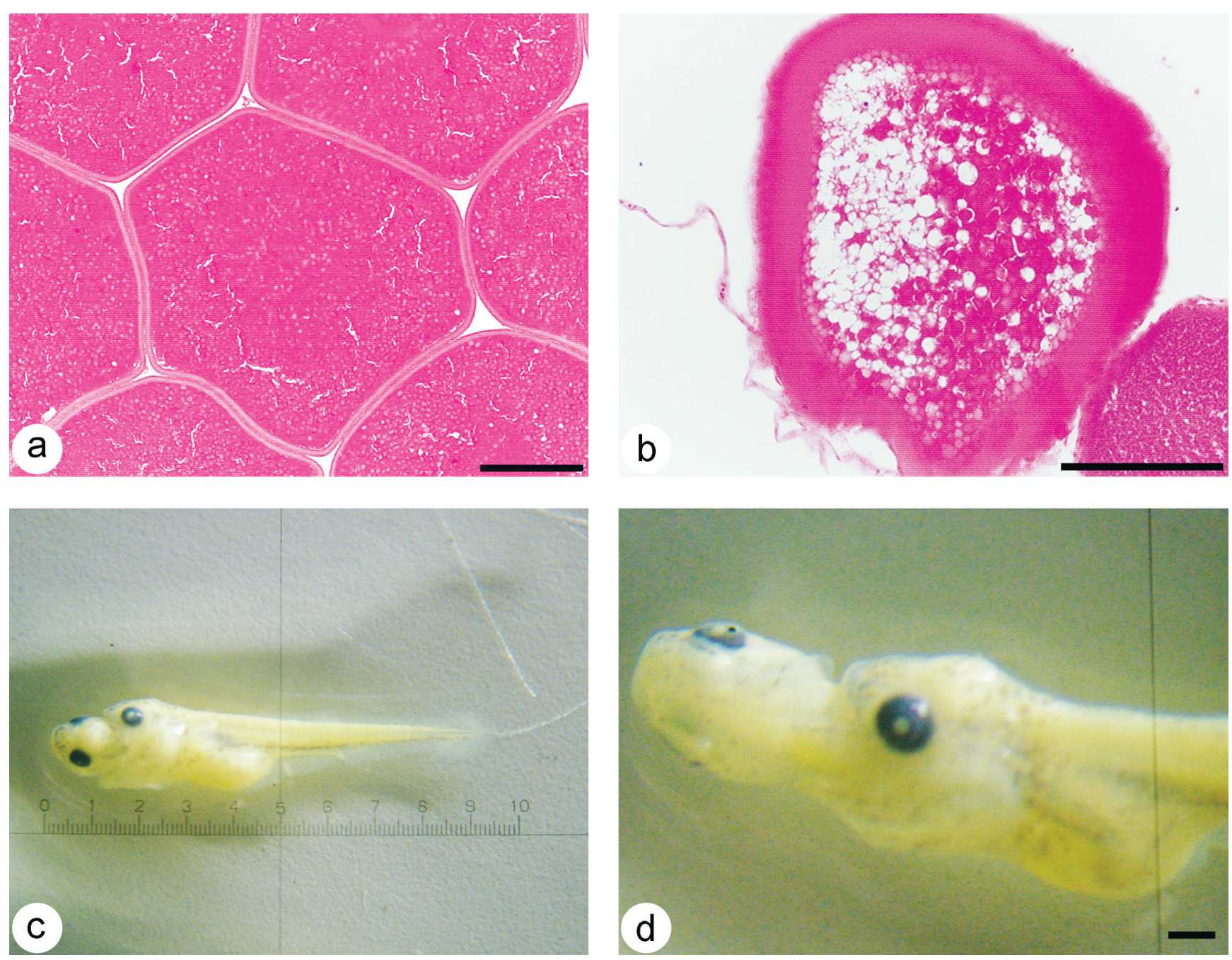

Fig. 2. Microscopic aspect of the ovaries and macroscopic aspect of Salminus hilarii larvae: a. micrograph of a mature ovary, showing the vitellogenic oocytes; b. micrograph of the ovary showing an atretic oocyte. Scale bars: (a) $300 \mu \mathrm{m}$ and (b) $100 \mu \mathrm{m}$; c. cannibalism among $S$. hilarii larvae; d. details of the larva head at the cannibalism moment (Scale bars $=1 \mathrm{~cm})$. 


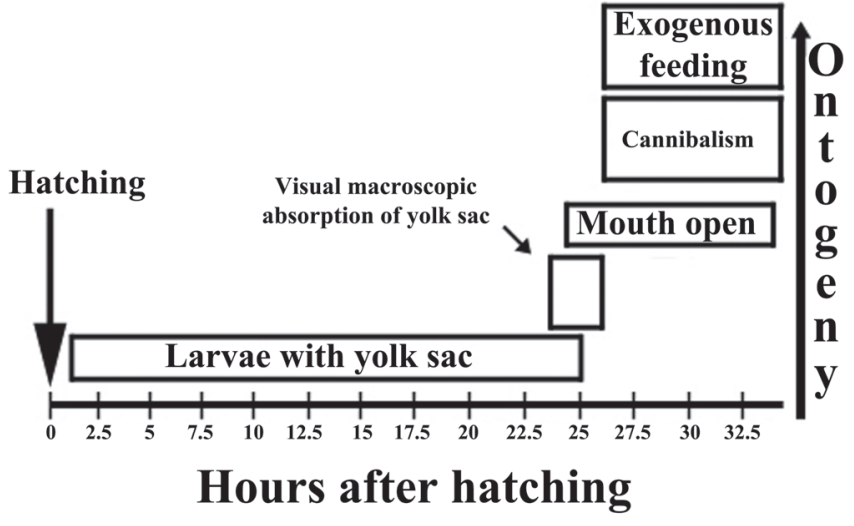

Fig. 3. Major events during the ontogeny of Salminus hilarii larvae.

followed by oocytes analysis. Considering that the ovulated oocyte has an average diameter of $1 \mathrm{~mm}$, the $5 \mathrm{~mm}$ polyethylene tubing used to cannulate the gonoduct was suitable, using the suggestion from Harvey \& Carolsfeld (1993) that the tubing diameter should be at least 2-3 times the oocyte diameter. The knowledge that $S$. hilarii vitellogenic oocytes account for $15-30 \%$ of the total oocytes and measure about $1.3 \mathrm{~mm}$ (Honji et al., 2009) was important information used to establish this broodstock selection. The general morphology of eggs and larvae from G1 and G2 did not differ during development. Therefore, this analysis was performed only to confirm the stage of development because details of this development have already been described by Honji et al. (2009).

The artificial breeding protocol established for natural spawning indicated an average HD of about 156. In this trial, the females spawned in the same day, so the water temperature did not vary, limiting the variation of HD from $130-170$ ( $156 \pm 3.14$ average). The HD is the sum of the mean water temperature per hour after the second female injection until spawning (Weingartner \& Zaniboni-Filho, 2005). The HD for $S$. hilarii is similar to other Salminus genus, such as $S$. brasiliensis, which has an HD of $150\left(25^{\circ} \mathrm{C}\right)$ (Weingartner \& Zaniboni-Filho, 2005). However, small variations in HD (from 134 to 150) are observed in S. brasiliensis (Sato et al., 1997). When spawning is close, males and females start swimming faster and near the water surface, almost jumping out of the water. This special behavior observed in fish is caused by pheromones released into the water and detected by the olfactory system of the partner, triggering spawning (Harvey \& Carolsfeld, 1993).

Hand-stripping, followed by dry gamete fertilization is considered a good technique for some species (Harvey \& Carolsfeld, 1993), including some species of Characidae (review in Baldisserotto \& Gomes, 2005) and also for $S$. brasiliensis (Weingartner \& Zaniboni-Filho, 2005). However, under the conditions of this experiment, this method was not successful for $S$. hilarii and resulted in no fertilization. We initially ascribed that failure to a possible intolerance to captivity by the wild broodstock. However, in this study, this hypothesis was later refuted because the fertilization failure occurred in both wild and domesticated animals, and the domesticated females were accustomed to a regular fish farm management.

The fertilization failure in hand-stripped $S$. hilarii broodstocks has also reported by the technician responsible for fingerling production in CESP (Companhia Energética do Estado de São Paulo) restocking programs in Barra Bonita, São Paulo (unpublished data) and S. brasiliensis fish farmers (Weingartner \& Zaniboni-Filho, 2005). Considering the lack of fertilization achieved in this study even after adjusting our protocol to a method that was successful in S. brasiliensis, is possible that other variables, such as oocyte and/or sperm quality, may be altered during manual stripping (Mylonas et al., 2010). This statement can be the cause of the results observed.

The gamete fertilization rate obtained for S. hilarii can be considered low for G1 and G2. The fertilization rate for S. brasiliensis was 80 to $90 \%$ in the São Carlos Fish Farm Station (Weingartner \& Zaniboni-Filho, 2005). However, for $S$. brasiliensis, the hand-stripping of oocytes was successful when considering the water volume discussed above and considerably increased the fertilization rate in relation to natural spawning. Many researchers obtained a higher fertilization rate than that obtained in this study using the hand-stripping technique with native species (review in Baldisserotto \& Gomes, 2005). The hand-stripping of oocytes increases the fertilization rate because it increases the chance of an encounter with gametes of the opposite sex. Moreover, the hand-stripping process decreases the handling of eggs, reduces mortality by infections (normally caused by fungus) and mechanical shocks, and increases the larval hatching rate. When spawning occurs naturally, it is necessary to handle the supposed fertilized eggs, increasing the rate of mortality. Additionally, even using all captive-reared males, individual sperm characteristics could have influenced the fertilization rate, as has been suggested for S. brasiliensis (Weingartner \& Zaniboni-Filho, 2005).

Despite the benefits of induced spawning in fish reproduction, there are some negative impacts on gamete quality attributed to spawning-induction techniques (Bobe \& Labbé, 2010). Compared to natural reproduction, lower hatch rates or low egg quality were obtained for European sea bass (Fornies et al., 2001), Senegal sole (Aguillero et al., 2006) and yellowtail flounder (Avery et al., 2004) when the broodstocks were artificially reproduced. This variability can be ascribed to a failure to detect the appropriate time for hormonal stimulation due to different stages of oocyte maturation (Bobe \& Labbé, 2010). Studies on the morphological aspects of eggs during ontogeny have been in progress to evaluate whether the eggs in G3 and G4 were not fertilized or if the developmental failure occurred after fertilization.

Studies about embryo development in teleost fish are applicable to fish farming. These studies can characterize the most important events during development, such as the total consumption of the yolk sac, the appearance of internal and 
external structures, mouth opening, and other characteristics (Sato et al., 1998; Nakatani et al., 2001; Sato et al., 2003; Borçato et al., 2004; Kamler, 2008). For carnivorous species, the exact timing of the mouth opening is important to indicate the time that the animal, until then considered to be within a closed system, enters into an open system, and therefore begins exogenous food intake.

In this study, $S$. hilarii larvae were cannibalistic. The production of larvae can be considered the limiting factor in the production of this species on a large scale, in addition to the low fertilization rate and the difficulties observed with dry fertilization of gametes when females are stripped. Histological analysis showed that the stage of maturation reached is adequate for induced ovulation, due to the presence of several vitellogenic oocytes and post-ovulatory follicles after induction. However, some oocytes were not released and became atretic (Dias et al., 1998, 2005; Honji et al., 2006, 2009). This phase of the development is observed and discussed in some works, including studies in S. hilarii (Takahashi, 2006; Honji et al., 2009).

This is the first study on the reproductive performance of $S$. hilarii in captivity, and it shows that artificial reproduction in captivity is possible using both wild and domesticated females. However, it is necessary to adjust handling strategies to improve the fertilization rate and alter post-hatching feeding protocols to reduce cannibalism and enhance fingerling production for restocking programs in impounded areas. Several factors contribute to the decline of a species. Increasingly, conservation biologists, mainly aquatic physiologists, support the recovery of this threatened species and the use of biological information to predict future problems (Philippart, 1995; Domínguez-Domínguez et al., 2002; Wikelski $\&$ Cooke, 2006). This information, resulting from field- and lab-based studies, is essential to ensure the success of conservation programs like the $S$. hilarii restocking program in the upper Tietê River basin.

\section{Acknowledgements}

This work was supported by a research grant from FAPESP (01/10483-1) and a Master's student fellowship (CNPq 134451/ 2005-8). The authors would also like to thank the fishermen who helped to collect the wild females as well as the DAEE (Departamento de Águas e Energia Elétrica do Governo do Estado de São Paulo) for allowing us to use the Ponte Nova Hatchery facilities.

\section{Literature Cited}

Aguillero, M. J., V. Anguis, J. P. Canavate, G. Martinez-Rodriguez, C. C. Mylonas \& J. Cerda. 2006. Induction of spawning of captive-reared Senegal sole (Solea senegalensis) using different administration methods for gonadotropin-releasing hormone agonist. Aquaculture, 257: 511-524.

Amutio, V. G., A. Espinach Ros \& A. Fortuny. 1986. Field-induced breeding of the Dorado, Salminus maxillosus Valenciennes. Aquaculture, 59: 15-21.
Andrade, D. R., A. L. Godinho, H. P. Godinho \& E. Shimoda. 2006. Biologia reprodutiva da tabarana, Salminus hilarii (Osteichthyes, Characidae) na represa de três Marias, MG. Revista Brasileira de Ciências Veterinária, 28(1): 26-32.

Avery, T. S., D. Boyce \& J. A. Brown. 2004. Mortality of yellowtail flounder, Limanda ferruginea (Storer), eggs: effects of temperature and hormone-induced ovulation. Aquaculture, 230: 297-311.

Baldisserotto, B. \& L. C. Gomes. 2005. Espécies nativas para piscicultura no Brasil. Santa Maria, Rio Grande do Sul, Ed. UFSM, 470p.

Bobe, J. \& C. Labbé. 2010. Egg and sperm quality in fish. General and Comparative Endocrinology, 165: 535-548.

Borçato, F. L., N. Bazzoli \& Y. Sato. 2004. Embriogenesis and larval ontogeny of the "piau-gordura", Leporinus piau (Fowler) (Pisces, Anostomidae) after induced spawning. Revista Brasileira de Zoologia, 21(1): 117-122.

Butts, I. A. E., E. A. Trippel \& M. K. Litvak. 2009. The effect of sperm to egg ratio and gamete contact time on fertilization success in Atlantic cod Gadus morhua L. Aquaculture, 286: 89-94.

Caneppele, D., R. M. Honji, A. W. S. Hilsdorf \& R. G. Moreira. 2009. Induced spawning of the endangered Neotropical species Steindachneridion parahybae (Siluriformes: Pimelodidae). Neotropical Ichthyology, 7(4): 759-762.

Castagnolli, N. \& M. C. Castagnolli. 2005. State of the art of Brazilian aquaculture. World Aquaculture, 36(1): 22-24.

Dias, J. F., C. B. Fiadi, H. L. N. Silbiger \& L. S. H. Soares. 2005. Reproductive and population dynamics of the Bay whiff Citharichthys spilopterus Günther, 1862 (Pleuronectiformes: Paralichthyidae) in the Mamanguá Inlet, Rio de Janeiro, Brasil. Neotropical Ichthyology, 3(3): 411-419.

Dias, J. F., E. Peres-Rios, P. T. C. Chaves \& C. L. D. B. RossiWongtschowski. 1998. Análise macroscópica dos ovários de teleósteos: problemas de classificação e recomendações de procedimentos. Revista Brasileira de Biologia, 58(1): 55-69.

Domínguez-Domínguez, O., S. Nandini \& S. S. S. Sarma. 2002. Larval feeding behavior of the endangered fish golden bubblebee goodeid, Allotoca dugesi, implications for conservation of an endangered species. Fisheries Management and Ecology, 9: 285-291.

Fornies, M. A., E. Mananos, M. Carrillo, A. Rocha, S. Laureau, C. C. Mylonas, Y. Zohar \& S. Zanuy. 2001. Spawning induction of individual European sea bass females (Dicentrarchus labrax) using different GnRHa-delivery systems. Aquaculture, 202: 221-234.

Godoy, M. P. 1975. Peixes do Brasil - Sub-ordem Characoidei. Bacia do Rio Mogi-Guaçu, Piracicaba, Editora Franciscana. Franciscana (Ed.), Vol. 4: 398p.

Gomes, L. C. \& E. C. Urbinati. 2005. Matrinxã (Brycon amazonicus). Pp. 149-174. In: Baldisseroto, B. \& L. C. Gomes. (Eds.). Espécies Nativas para piscicultura no Brasil. Santa Maria, Rio Grande do Sul. Ed. UFSM, 470p.

Harvey, B. \& J. Carolsfeld. 1993. Induced breeding in tropical fish culture. International Development Research Centre. Ottawa, Canada. International Development Research Centre, 144p.

Honji, R. M., A. M. Narcizo, M. I. Borella, E. Romagosa \& R. G. Moreira. 2009. Patterns of oocyte development in natural habitat and captive Salminus hilarii Valenciennes, 1850 (Teleostei: Characidae). Fish Physiology and Biochemistry, 35: 109-123.

Honji, R. M., A. M. Vaz-dos-Santos \& C. L. D. B. RossiWongtschowski. 2006. Identification of the stages of ovarian maturation of the argentine hake Merluccius hubbsi Marini, 1933 (Teleostei: Merluciidae): advantages and disadvantages of the use of the macroscopic and microscopic scales. Neotropical Ichthyology, 4(3):329-337. 
von Ihering, R. 1929. Da vida dos peixes. Ensaios e scenas de pescarias. Companhia Melhoramentos de São Paulo. Editora Proprietária, $150 \mathrm{p}$.

von Ihering, R. \& P. Azevedo. 1934. A curimatã dos açudes nordestinos (Prochilodus argenteus). Archivos do Instituto Biológico, 5(5):143-184.

von Ihering, R. \& P. Azevedo. 1936. A desova e a hipofisação dos peixes. Evolução de dois Nematognathas. Archivos do Instituto Biológico, 7(9): 107-180.

Ituassú, D. R., B. A. S. Cavero, F. A. L. Fonseca \& A. M. Bordinhon. 2005. Cultivo de curimatã (Prochilodus spp.). Pp. 67-79. In: Baldisseroto, B. \& L. C. Gomes. (Eds.). Espécies Nativas para piscicultura no Brasil. Santa Maria, Rio Grande do Sul. Ed. UFSM, 470p.

Kamler, E. 2008. Resource allocation in yolk-feeding fish. Reviews in Fish Biology and Fisheries, 18: 143-200.

Lima, F. C. T. \& H. A. Britski. 2007. Salminus fransciscanus, a new species from the rio São Francisco Basin, Brazil (Ostariophysi: Characiformes: Characidae). Neotropical Ichthyology, 5(3): 237-244.

Lima, F. C. T., P. A. Buckup, N. A. Menezes, C. A. S. Lucena, Z. M. S. Lucena, M. Toledo-Piza \& A. Zanata. 2007. Família Characidae: gêneros incertae sedis. Pp. 44-62. In: Buckup, P. A., N. Menezes \& M. S. Ghazzi (Eds.). Catálogo das espécies de peixes de água doce do Brasil. Série Livros 23. Museu Nacional. Universidade Federal do Rio de Janeiro, 195p.

Lima, F. C. T., L. R. Malabarba, P. A. Buckup, J. F. Pezzi da Silva, R. P. Vari, A. Harold, R. Benine, O. T. Oyakawa, C. S. Pavanelli, N. A. Menezes, C. A. Lucena, M. C. S. L. Malabarba, Z. M. S. Lucena, R. E. Reis, F. Langeani, L. Cassati, V. A. Bertaco, C. Moreira \& P. H. F. Lucinda. 2003. Genera incertae sedis in Characidae. Pp. 106-169. In: Reis, R. E., S. O. Kullander \& C. J. Ferraris (Eds.). Check list of the freshwater fishes of South and Central America. Porto Alegre, Edipucrs, 729p.

Mirande, J. M. 2010. Phylogeny of the family Characidae (Teleostei: Characiformes): from characters to taxonomy. Neotropical Ichthyology, 8(3): 385-568.

Mylonas, C. C., A. Fostier \& S. Zanuy. 2010. Broodstock management and hormonal manipulations of fish reproduction. General and Comparative Endocrinology, 165: 516-534.

Nakatani, K., A. A. Agostinho, G. Baumgartner, A. Bialtzki, P. V. Sanches, M. C. Makrakis \& C. S. Pavanelli. 2001. Ovos e larvas de peixes de água doce: desenvolvimento e identificação. Maringá, Eduem, 378p.

Philippart, J. C. 1995. Is captivity breeding an effective solution for the preservation of endemic species? Biological Conservation, 72: 281-295.

Porto-Foresti, F., R. B. Castilho-Almeida \& F. Foresti. 2005. Biologia e criação do lambari-do-rabo-amarelo (Astyanax altiparanae). Pp. 105-120. In: Baldisseroto, B. \& L. C. Gomes. (Eds.). Espécies Nativas para piscicultura no Brasil. Santa Maria, Rio Grande do Sul, Ed. UFSM, 470p.
São Paulo. 2008. Decreto Estadual no 53494-2008 de 02 de outubro de 2008. Diário Oficial do Estado de São Paulo 118 (187) Secretaria do Meio Ambiente.

Sato, Y., N. Fenerich-Verani, J. R. Verani \& H. P. Godinho. 2003. Induced reproductive responses of the neotropical anostomid fish Leporinus elongatus Val. under captive breeding. Aquaculture Research, 31: 189-193.

Sato, Y., N. Fenerich-Verani, J. R. Verani, H. P. Godinho \& E. V. Sampaio. 1998. Induced reproduction and reproductive characteristics of Rhinelepis aspera Agassiz, 1829 (Ostheichthyes: Siluriformes, Loricariidae). Brazilian Archives of Biology and Technology, 40(3): 309-314.

Sato, Y., N. Fenerich-Verani, J. R. Verani, H. P. Godinho \& L. J. S. Vieira. 1997. Reprodução artificial do dourado Salminus brasiliensis (Pisces: Characidae) da bacia do rio São Francisco. Revista Brasileira de Reprodução Animal, 21(3): 113116.

Takahashi, E. L. H. 2006. Ciclo reprodutivo da tabarana Salminus hilarii (Valenciennes, 1849) (Characidae, Salmininae) na região do baixo Rio Sorocaba, SP. Unpublished M.Sc. Dissertation, Universidade Estadual Paulista. Centro de Aquicultura. Jaboticabal, 202p.

Urbinati, E. C. \& F. D. Gonçalves. 2005. Pacu (Piaractus mesopotamicus). Pp. 225-255. In: Baldisseroto, B. \& L. C. Gomes. (Eds.). Espécies Nativas para piscicultura no Brasil. Santa Maria, Rio Grande do Sul, Ed. UFSM, 470p.

Vazzoler, A. E. A. M. 1981. Manual de métodos para estudos biológicos de populações de peixes: reprodução e crescimento. Brasília, CNPq, 108p.

Vazzoler, A. E. A. M. 1996. Biologia da reprodução de peixes teleósteos: teoria e prática. Maringá, EDUEM, 169p.

Weingartner, M. \& E. Zaniboni-Filho. 2005. Dourado. Pp. $257-$ 286. In: Baldisseroto, B. \& L. C. Gomes. (Eds.). Espécies Nativas para piscicultura no Brasil. Santa Maria, Rio Grande do Sul, Ed. UFSM, 470p.

Wikelski, M. \& S. J. Cooke. 2006. Conservation physiology. Trends in Ecology \& Evolution, 21(2): 38-46.

Zaniboni-Filho, E. \& N. D. C. Barbosa. 1996. Priming hormone administration to induce spawning of some brazilian migratory fish. Revista Brasileira de Biologia, 56(4): 655-659.

Zaniboni-Filho, E. \& M. Weingartner. 2007. Técnicas de indução da reprodução de peixes migradores. Revista Brasileira de Reprodução Animal, 31(3): 367-373.

Zar, J. H. 1999. Biostatistical analysis. New Jersey, ( $4^{\circ}$ Ed.). Prentice Hall, 663p.

Zohar, Y. \& C. C. Mylonas. 2001. Endocrine manipulations of spawning in cultured fish: from hormones to genes. Aquaculture, 197: 99-136.

Accepted January 5, 2011

Published June 30, 2011 